УДК 811.111’255 (075.8)

DOI https://doi.org/10.26661/2414-1135-2021-82-6

\title{
КРИТЕРІЇ ОЦІНЮВАННЯ ЯКОСТІ УСНОГО ПЕРЕКЛАДУ
}

\author{
Гончаренко Л. О. \\ кандидат філологічних наук, доцент, \\ дочент кафедри романо-германської філології та перекладу з німецької мови \\ Чорноморський національний університет імені Петра Могили \\ вул. 68 Десантників, 10, Миколаїв, Украӥна \\ orcid.org/0000-0002-9541-952X \\ stotskaya07@rambler.ru
}

\author{
Ключові слова: \\ еквівалентність, \\ адекватність, перекладацька \\ компетенція, переклад \\ конференцій, синхронний \\ переклад.
}

Стаття присвячена дослідженню питання досягнення якості усного перекладу в процесі виступів на переговорах і конференціях. Аналізуючи підходи провідних вітчизняних і зарубіжних перекладознавців, у статті обгрунтовуємо актуальність розмежування базових понять оцінки ефективності перекладних текстів у письмовій та усній комунікаціях. При цьому вказується різниця в способах оцінки письмового й усного перекладу, розглядаються поняття еквівалентності й адекватності як основні чинники оцінювання ефективності перекладу. Досягнення адекватності в усному переговорному процесі, зокрема прагматичної адекватності, розглядається як найбільш релевантний спосіб досягнення мети комунікації. Проводиться огляд актуальних методичних прийомів, представлених у роботах сучасних теоретиків і практиків усного перекладу, а також розглядаються найбільш ефективні види спеціальних вправ. На конкретних прикладах демонструються прийоми подолання можливих ускладнень у процесі усної комунікації за допомогою застосування спеціальних перекладацьких умінь і навичок, що дає змогу досягти адекватного перекладу. Також наголошується на важливості набуття спеціальних компетенцій усного перекладача в ході навчання. Говорячи про оцінку якості усного перекладу, логічно виходити 3 критеріїв досягнення адекватності, передусім передаючи зміст висловлювання, при цьому завжди прагнути досягти бажаного прагматичного впливу на тих, кому цей переклад призначений. Цілком природньо, що залежно від тематики й формату здійснення усного послідовного перекладу перекладу з аркуша або синхронного перекладу адекватність досягається різними способами, але при цьому центром комунікативного процесу $є$ перекладач, що має необхідні психологічні якості, такі як комунікативна гнучкість, стресостійкість, ерудованість, і володіє відповідними прийомами досягнення необхідної адекватності перекладу в будь-якій ситуації. 


\title{
QUALITY EVALUATION CRITERIA OF INTERPRETATION
}

\author{
Honcharenko L. O. \\ Candidate of Philological Sciences, Associate Professor, \\ Associate Professor at the Department of Romano-Germanic Philology \\ and Translation from German \\ Petro Mohyla Black Sea National University \\ 68 Desantnykiv str., 10, Mykolaiv, Ukraine \\ orcid.org/0000-0002-9541-952X \\ stotskaya07@rambler.ru
}

\begin{abstract}
Key words: translation equivalency, adequacy, translation competences, conference translation, simultaneous translation.
\end{abstract}

\begin{abstract}
The article discusses the issues of achieving the high quality interpretation at conferences and negotiations. The purpose of the article is to determine the criteria for evaluating interpretation. Analyzing the approaches of leading nativ and foreign translators, in the article is justified the need to differentiate the basic concepts of assessing the effectiveness of translation and interpretation. Similarly, the article differentiates the methods of evaluating the translation and interpretation, describes the concepts of equivalence and adequacy of translation, which are considered the main factors in measuring the effectiveness of translation and interpretation. Achieving adequacy in interpreting, particularly, pragmatic adequacy, is viewed as the most relevant way to achieve the goal of communication. The article reviews the actual methodical techniques presented in the works of modern theorists and practitioners of translation and interpretation, and also examines the most effective types of special exercises used by the author of the article in practice. Specific examples demonstrate the ways of overcoming possible complications in the process of oral communication through the use of special translation skills and tools, which allows achieving adequate translation. The article also emphasizes the importance of acquiring special interpretation competences in linguistic education of universities. Speaking about the quality evaluation criteria of interpretation, it is logical to proceed from the criteria of achieving adequacy, first of all, conveying the meaning of the statement, while always striving to achieve the desired pragmatic impact on those for whom this translation is intended. Absolutely, depending on the topic and format of consecutive interpretation, translation from a sheet or simultaneous translation, adequacy is achieved in different ways, but the center of the communicative process is a translator with the necessary psychological qualities such as communication flexibility, stress, erudition and has the appropriate techniques to achieve the required adequacy of translation in any situation.
\end{abstract}

Постановка проблеми. Що б не писали або не говорили про переклад, основною проблемою завжди було й залишається - як перекласти якісно. Водночас якість перекладу обговорюється століттями. Не припиняється дискусія про переваги того чи іншого методу вибору еквівалентів, розробляються техніки письмового та машинного перекладу. Критиці також піддаються переклади художніх творів [1]. Серед усіх цих відмінностей одна полягає в тому, що всі точки зору на переклад відносно постійні: переклад повинен відповідати певним правилам і дотримання цих правил неминуче призведе до якісно еквівалентного або відповідного перекладу [2, с. 90].
Мета й завдання статті. Метою статті $\epsilon$ спроба визначити, який стандарт варто використовувати для встановлення якості усного перекладу, проаналізувавши при цьому його види й ознаки, оскільки письмовий та усний переклад не може бути оцінений за однаковими критеріями.

Предмет та об'скт дослідження. Предметом дослідження $\epsilon$ усний переклад, предметом дослідження є критерії оцінювання якості усного перекладу.

Виклад основного матеріалу дослідження. У наукових роботах 3 теорії та практики усного перекладу Д. Селескович та М. Ледерер підкреслюється єдність лінгвістичних і психологічних 
факторів як незаперечна основа усного перекладу [3], при цьому перекладач у процесі усного перекладу має справу передусім зі смислом тексту, іноді вимушено нехтуючи повнотою змісту, що цілком очевидно підтверджується практикою усного переговорного процесу.

Аналіз виступів у процесі переговорів, а також огляд статей провідних перекладознавців показує, що для оцінки усного перекладу в більшості випадків використовується термін «адекватність» [4, с. 58]. При цьому під адекватністю розуміють такий текст перекладу, який вирішує основне прагматичне завдання, тобто $є$ комунікативно і прагматично еквівалентним у конкретній ситуації перекладацького процесу, відповідає цій ситуації, передаючи зміст тексту, іноді навіть за рахунок деяких відступів від змісту, наприклад, нехтуючи зайвими подробицями викладу місцевих регіональних реалій незрозумілих слухачеві. У такому випадку, якщо це не суперечить рішенню прагматичного завдання, перекладач може вдатися до генералізації.

Підготовка до усного перекладу повинна базуватися на тренінгу окремих тем (галузей), що дасть змогу в процесі послідовного перекладу прогнозувати певний лексичний склад висловлювання в межах заданого тематичного ряду, обробки й розширення бази прецизійної інформації, по суті, доведення до автоматизму впізнавання географічних назв, чисел, дат, у тому числі культурно маркованих для певної сторони учасників переговорного процесу, а крім того, необхідно розвивати вміння «гнучкості» перекладача, тобто вміння знаходити перекладацьку відповідність, еквівалент у процесі перекладу, навіть у тому випадку, якщо немає в запасі відповідного терміна, а перепитати під час виступу оратора неможливо, а зволікання призводить до неминучого провалу комунікації, не кажучи вже про адекватність перекладу [5].

При здійсненні послідовного перекладу від перекладача не потрібно миттєвого відтворення сказаного, як це відбувається при синхронному перекладі, але цей вид також вимагає великих розумових і фізичних затрат. Перекладачеві протягом багатьох годин доводиться запам'ятовувати великі обсяги тексту, від нього вимагається точна передача суті сказаного, грамотність і культура мови, лаконічність і вміння чітко висловлювати думки. Також при послідовному перекладі відразу стає видно різницю між добре підготовленим професіоналом і його менш досвідченим колегою. Не можна не відзначити також особливостей усного послідовного перекладу, до яких відносяться культурні розбіжності в парадигмі мов. Знання міжкультурних відмінностей, традицій, особливостей менталітету як наслідки взаємодії культурних картин світу комунікантів [6, с. 25-27]. Вони повинні стати невід'ємною частиною професійної компетенції усного перекладача [3].

Тренування вмінь і навичок різних підвидів усного перекладу проводиться на заняттях в аудиторії й відпрацьовується вдома. Основи методики навчання усного перекладу, система вправ щодо вміння імовірнісного прогнозування, тренування прецизійної інформації закладені в роботах Р. Міньяра-Белоручева, В. Комісарова $[2 ; 4]$. Велика увага професійним навичкам усного перекладу приділяється в роботах I. Алексєєвої, М. Вербицької, І. Зубанова, де детально описані вправи на тренування довгострокової й короткочасної пам'яті, риторичних умінь синхронізації механізмів читання та промовляння $[7 ; 8 ; 9]$.

Найбільш істотний етап усного перекладу являє собою ряд розумових операцій, які відбуваються в мозку перекладача. Р. Міньяр-Бєлоручев називає цю особливість процесу перекладу «невловимістю», «невідчутністю» його деяких сторін [4]. Процес усного перекладу можна описати за допомогою психолінгвістичної моделі. У їі основі лежить психолінгвістична модель мовленнєвої діяльності. Вона передбачає наявність мети, внутрішньої програми майбутнього висловлювання, побудови висловлювання у внутрішньому мовленні та його вербалізацію в усній мові. Внутрішня програма перекладача представляє стислий зміст оригіналу, оскільки в процесі своєї діяльності перекладач не створює власних висловлювань.

Відповідно до цієї моделі, переклад здійснюється у два етапи:

1) перекладач «перекладає» зміст оригіналу, який він зрозумів, «мовою мозку» у вигляді своєї внутрішньої програми;

2) він розгортає цю програму іншою мовою, так як це робить будь-який носій цієї мови [10].

Що стосується стратегій у синхронному перекладі, то це засіб для досягнення перекладацького завдання, що полягає в адекватній передачі з іноземної мови мовою перекладу комунікативної інтенції відправника з урахуванням культурологічних та особистісних особливостей оратора, базового рівня, мовної надкатегорії й підкатегорії [11]. Із цього визначення випливає, що під стратегією розуміється сукупність як лінгвістичних, так і екстралінгвістичних чинників, на які опирається перекладач при виборі того чи іншого методу виконання перекладацького завдання на цій ділянці перекладу.

Сьогодні в науці часто порушується питання, у яких мовних парах виконання синхронного перекладу становить найбільшу складність. Суперечка зав'язана на синтаксичній структурі найбільш популярних для синхронного перекладу мов: арабської, іспанської, китайської, японської, португальської, російської, італійської, англійської, 
французької й німецької. Справа в тому, що серед цих мов три 3 них відрізняються такою структурою будови речення, при якій дієслово знаходиться в кінці. В арабській мові дієслово часто ставиться в самий початок речення. Однак труднощі синхронного перекладу загалом не залежать від тієї чи іншої мовної пари. Проте вчені розділені в цьому питанні на дві протилежні за поглядами групи. На думку перших, переклад із таких мов, як китайська, японська та німецький, наприклад, англійською та французькою - процес більш складний, ніж переклад 3 англійської або французької китайською, німецькою або японською. На їхню думку, коли мова йде про переклад 3 китайської англійською, варто застосовувати низку стратегій, властивих саме цій мовній парі. Деякі дотримуються іншої думки: виходячи 3 основного завдання перекладу, а саме передачі змісту повідомлення, відмінності в синтаксичній структурі не є серйозною перешкодою для здійснення синхронного перекладу [12].

В. Ілюхін виділяє дві групи стратегій у синхронному перекладі: стратегії, засновані на факторі часу, і стратегії, які пов'язані зі статистичними факторами [11]

Стратегія спроб $i$ помилок застосовується тоді, коли вузький контекст мовою оригіналу не дає перекладачеві переконатися в правильності обраного варіанта перекладу. У таких випадках $\epsilon$ необхідність в отриманні широкого контексту для адекватної передачі фрагмента мовою перекладу.

Стратегія очікування використовується в тих випадках, коли синхроніст потребує широкого контексту для більш адекватної передачі сегмента. Застосування цієї стратегії можливо лише в тому випадку, коли доповідач розширює контекст відразу після промови цього сегмента.

Головна відмінність у застосуванні стратегії столінгу від застосування стратегії очікування полягає в тому, що пауза між сказаним оратором сегментом і розширенням контексту для перекладу цього сегмента триває досить довго. У подібних умовах застосування стратегії очікування неможливе, тому синхроніст змушений заповнювати паузу тематичною інформацією в очікуванні широкого контексту.

Стратегія лінійності дає можливість перекладачеві зробити синтаксичну структуру мовою перекладу більш простою. Цей процес призводить до кращого розуміння перекладного сегмента, так як короткі відрізки перекладеної інформації легше сприймаються на слух.

Стратегія знакового перекладу може бути застосована тоді, коли в мові оратора виникає незнайомий для перекладача термін. Використання цієї стратегії призводить до появи в тексті перекладу буквалізмів.
Застосування стратегії компресії можливо завдяки предметній ситуації, під якою розуміють також соціокультурний аспект. На використання цієї стратегії перекладача штовхає високий темп мови оратора.

Стратегія декомпресії може бути застосована при перекладі як термінів, так і незнайомих перекладачеві слів. Компенсація є основним складником застосування цієї стратегії. Декомпресія застосовується тоді, коли виникає необхідність широко розгорнути використане в тексті оригіналу поняття [13].

Отже, синхроніст користується певною стратегією протягом перекладу. Вона може змінюватися залежно від лінгвістичних та екстралінгвістичних факторів, які здійснюють прямий вплив на ії вибір перекладачем. Як правило, під час перекладу синхроніст користується декількома стратегіями, які він змінює залежно від обставин. У низці випадків зміна стратегії відбувається раптово, коли перекладачеві стає зрозумілим, що обрана стратегія із самого початку не призведе до досягнення поставленої мети.

Висновки й перспективи подальших розробок. Таким чином, говорячи про оцінку якості усного перекладу, логічно виходити зі стандарту досягнення адекватності, передаючи передусім зміст висловлювання, і водночас завжди прагнути досягти бажаного прагматичного впливу на тих, на кого розрахований цей переклад. Залежно від тематики й форми здійснення усного послідовного перекладу або синхронного перекладу адекватність досягається різними способами, але при цьому центром комунікативного процесу є перекладач, який володіє необхідними психологічними якостями, такими як комунікативна гнучкість, стресостійкість, ерудованість, i володіє прийомами досягнення адекватності перекладу в будь-якій ситуації. Перспективою подальших досліджень у досягненні якості усного перекладу може стати поглиблене вивчення матеріалу в межах усного перекладу будь-якого дискурсу, а також усних переговорів побутового формату.

\section{ЛIТЕРАТУРА}

1. Kussmaul P. Training the translator. Amsterdam : John Benjamin's Publishing Company, 1995. 160 p.

2. Комиссаров В.Н. Общая теория перевода. Москва : ЧЕРО, 1999. 136 с.

3. Seleskovich D., Lederer. M. Interpreter Pour Traduire. Paris, 1996. 311 p.

4. Миньяр-Белоручев Р.К. Записи в последовательном переводе. Москва : Проспект АП, 2005. $176 \mathrm{c}$.

5. Чужакин А.Н. Мир перевода 7. Прикладная теория устного перевода и переводческой скорописи. Москва : Р. Валент, 2003. 232 с. 
6. Брега О.Н. Оценка уровня сформированности профессиональной межкультурной метаязыковой компетенции. Вектор науки Тольяттинского государственного университета. Серия «Педагогика, психология». Тольятти, 2017. № 2 (29). C. 25-30.

7. Алексеева И.С. Профессиональное обучение переводчика : учебное пособие по устному и письменному переводу для переводчиков и преподавателей. Санкт-Петербург : Союз, 2001. $288 \mathrm{c}$.

8. Вербицкая М.В., Беляева Т.Н., Быстрицкая Е.С. Устный перевод. Английский язык. Москва : Глосса-Пресс, 2008. Часть 1. 384 с.

9. Зубанова И.С. Английский язык. Скоропись в последовательном переводе $(+2 \mathrm{CD})$. Москва : Р. Валент, 2016. 216 с.

10. Комісаров В.Н. Сучасне перекладознавство. Москва : ЭТС, 2002. 420 с.

11. Илюхин В.М. Стратегии в синхронном переводе (на материале англо-русской и русскоанглийской комбинаций перевода) : дисс. ... канд. филол. наук : 10.02.20. Москва, 2001. $215 \mathrm{c}$.

12. Setton R. A Pragmatic Theory of Simultaneous Interpretation : doctoral dissertation. Ann Arbor. Michigan, 1997. 214 p.

13. Снєгірьова Є.В. Компресія і втрати змісту при синхронному перекладі: як не перейти межу. Лінгвістика ХХІ століття: нові дослідження $i$ перспективи. Київ : Логос, 2010. Вип. 5. C. 206-214.

\section{REFERENCES}

1. Kussmaul P. (1995) Training the translator. Amsterdam: John Benjamin's Publishing Company.

2. Komissarov V. N. (1999) Obshchaya teoriya perevoda [General translation theory]. Moscow: CHERO (in Russian).

3. Seleskovich D., Lederer M. (1996) Interpreter Pour Traduire. Paris.

4. Minyar-Beloruchev R. K. (2005) Zapisi v posledovatelnom perevode [Consecutive translation notes]. Moscow: Prospekt AP (in Russian).
5. Chuzhakin A. N. (2003) Mir perevoda 7 [The World of Translation]. Applied Theory of Interpretation and Interpreting Cursive Writing. Moscow: «R. Valent» (in Russian).

6. Brega O. N. (2017) Otsenka urovnya sformirovannoi professionalnoy mezhkulturnoy metayazykovoy kompetentsii [Assessment of the level of formation of professional intercultural metalanguage competence]. Science Vector of Togliatti State University. Series "Pedagogy, Psychology", no. 2(29), pp. 25-30 (in Russian).

7. Alekseeva I. S. (2001) Professionalnoe obuchenie perevodchika [Professional training of a translator]: A textbook on interpretation and translation for translators and teachers. Sankt-Peterburg: Soyuz (in Russian).

8. Verbitskaya M.V., Belyaeva T.N., Bystritskaya E.S. (2008) Ustnyy perevod. Angliyskiy yazyk [Oral translation. English]. Part 1. Moscow: Glossa-Press (in Russian).

9. Zubanova I. S. (2016) Angliyskiy yazyk. Skoropis $\mathrm{V}$ posledovatelnom perevode $(+2 \mathrm{CD})$ [English language. Cursive writing in consecutive translation (+2CD)]. Moscow: «R. Valent» (in Russian).

10. Komissarov V. N. (2002) Suchasne perekladoznavstvo [Modern translation studies]. Moscow: ETS (in Ukrainian).

11. Ilyukhin V. M. (2001) Strategii v sinkhronnom perevode (na materiale anglo-russkoy i russko-angliyskoy kombinatsiy perevoda) [Strategies in simultaneous translation (based on the material of the English-Russian and Russian-English translation combinations)]. (PhD Thesis), Moscow (in Russian).

12. Setton R. A (1997) Pragmatic Theory of Simultaneous Interpretation / doctoral dissertation. Ann Arbor. Michigan.

13. Snegireva E. V. (2010) Kompresiya i vtraty zmistu pry synkhronnomu perekladi: yak ne pereyty mezhu [Compression and loss of content in simultaneous translation: how not to cross the border] Linguistics of the XXI century: new research and prospects: a collection of scientific papers, vol. 5. Kyyiv: Logos, pp. 206-214 (in Ukrainian). 